\title{
Atopidae (Trilobita) in the upper Marianian (Cambrian Series 2, Stage 4) of Iberia
}

\author{
Luis Collantes, ${ }^{1}$ [D Eduardo Mayoral, ${ }^{1,2}$ (B) Eladio Liñán, ${ }^{3}$ (D) and Rodolfo Gozalo ${ }^{4}$ (1) \\ ${ }^{1}$ Departamento de Ciencias de la Tierra, Facultad de Ciencias Experimentales, Campus de El Carmen, Universidad de Huelva, Avda. 3 de \\ Marzo, s/n, 21071 Huelva, Spain <luis.collantes.geo@gmail.com><mayoral@uhu.es> \\ ${ }^{2} \mathrm{CCTH}$ - Centro de Investigación Científico Tecnológico, Universidad de Huelva, Avda. 3 de Marzo, s/n, 21071 Huelva, Spain \\ ${ }^{3}$ Departamento de Ciencias de la Tierra, Facultad de Ciencias-Instituto de Ciencias Ambientales (IUCA), Universidad de Zaragoza, 50009 \\ Zaragoza, Spain <linan@unizar.es> \\ ${ }^{4}$ Departamento de Botánica y Geología, Universitat de València, Dr. Moliner 50, 46100 Burjassot, Spain <rodolfo.gozalo@uv.es>
}

\begin{abstract}
New atopid trilobites are described from the early Cambrian Cumbres beds and Herrerías shale of northern Huelva Province (Andalusia, Spain) and are dated as middle-late Marianian (Cambrian Series 2, Stage 4). New specimens of Atops calanus Richter and Richter, 1941 are described and the Laurentian species Pseudatops reticulatus (Walcott, 1890b) is recognized for the first time in the Mediterranean subprovince. The associated trilobite assemblage studied herein suggests an age close to the base of Cambrian Stage 4.
\end{abstract}

\section{Introduction}

Atopidae Hupé, 1954 is a little investigated trilobite family based on Atops Emmons, 1844. Family membership has had a long and contentious history (Howell and Stubblefield, 1950) and constituent genera were regularly included in the Conocoryphidae based on their secondary blindness; this assignment continued beyond Hupe's (1954) erection of the family (Harrington et al., 1959; Korobov, 1973; Jell et al., 1992). In Spain, this genus was doubtfully recognized by Richter and Richter (1941) as Atops? calanus Richter and Richter, 1941 in the 'Fauna von Cala' from Huelva, and that occurrence has been cited by Lotze (1958, 1961) and Sdzuy (1961, 1962). Herein, we describe several cranidia and fragments that enable positive assignment to Atops.

Pseudatops Lake, 1940 is described for the first time in the Iberian Peninsula, with recognition of the Taconic North American species Pseudatops reticulatus (Walcott, 1890b). Its presence allows biostratigraphic and paleobiogeographic correlations with other Avalonian and Taconic localities.

\section{Geological setting}

The trilobites were collected in northern Huelva Province, southwestern Spain (Fig. 1), in the Sierra de Aracena y Picos de Aroche Natural Park. Cambrian rocks of the Ossa-Morena Zone are placed in distintict belts or 'blocks' - named 'Cubetas' in Spanish - with a notable change of facies and thickness, most likely related to downthrow and tilting along an active growth fault at the time of sediment deposition (Liñán and Quesada, 1990) (Fig. 1).

The stratigraphy of the different Cambrian blocks in northern Huelva has been little studied. Only early Cambrian formations have been established (Collantes et al., 2020) although not formally defined.
In the Cumbres block (Cumbres Cubeta), the siliciclastic sandstones and shales of the Cumbres beds (350-1100 m) are dated as middle-late Marianian, based on the trilobites Delgadella Walcott, 1912, Hicksia Delgado, 1904, Rinconia Hupé, 1953, and Triangulaspis Lermontova, 1940 in the lower part and Serrodiscus Richter and Richter, 1941 and Triangulaspis in the upper part (Liñán and Mergl, 1982; Liñán et al., 2002). The Cumbres fossil site (CU1) is located in the upper Cumbres beds (Collantes et al., 2020). The 24-m section at CU1 is between $38^{\circ} 02^{\prime} 45.74^{\prime \prime} \mathrm{N}, \quad 006^{\circ} 43^{\prime} 07.40^{\prime \prime} \mathrm{W}$ and $38^{\circ}$ $02^{\prime} 43.90^{\prime \prime} \mathrm{N}, 006^{\circ} 43^{\prime} 07.80^{\prime \prime} \mathrm{W}$. Atopid trilobites occur 17, 19, and $20 \mathrm{~m}$ from the base in association with Serrodiscus silesius Richter and Richter, 1941, Calodiscus ibericus Sdzuy, 1962, Triangulaspis fusca Sdzuy, 1962, Hicksia? sp. indet., Marocella morenensis (Yochelson and Gil Cid, 1984), brachiopods, and hyoliths.

In the Herrerías block (Herrerías Cubeta), the Herrerías shale (200-500 m) (Schneider in Richter and Richter, 1941) consists of purple shales with spilitic intercalations and has an age ranging from middle to late Marianian, based on Delgadella, Rinconia, Atops, Gigantopygus Hupé, 1953, Hicksia, Protaldonaia Sdzuy, 1961, Sdzuyomia Lieberman, 2001, and Strenuaeva Richter and Richter, 1940 in the lower part and Serrodiscus, Calodiscus Howell, 1935, and Triangulaspis in the upper part (Richter and Richter, 1941; Sdzuy, 1962; Ruiz López et al., 1979; Liñán and Mergl, 1982). The El Pozuelo fossil site (POZ1) is in the upper level Herrerías shale with Serrodiscus silesius, C. ibericus, Protaldonaia morenica Sdzuy, 1961, Delgadella sp. indet., Strenuaeva sp. indet., Marocella morenensis, and brachiopods. Base and top of the $48-\mathrm{m}$ section at the collecting site are at $37^{\circ} 58^{\prime} 59.17^{\prime \prime} \mathrm{N}$, $006^{\circ} 24^{\prime} 18.92^{\prime \prime} \mathrm{W}$ and $37^{\circ} 58^{\prime} 56.90^{\prime \prime} \mathrm{N}, 006^{\circ} 24^{\prime} 19.93^{\prime \prime} \mathrm{W}$, respectively, with atopid trilobites 7 and $9 \mathrm{~m}$ from the base (Collantes et al., 2020). 


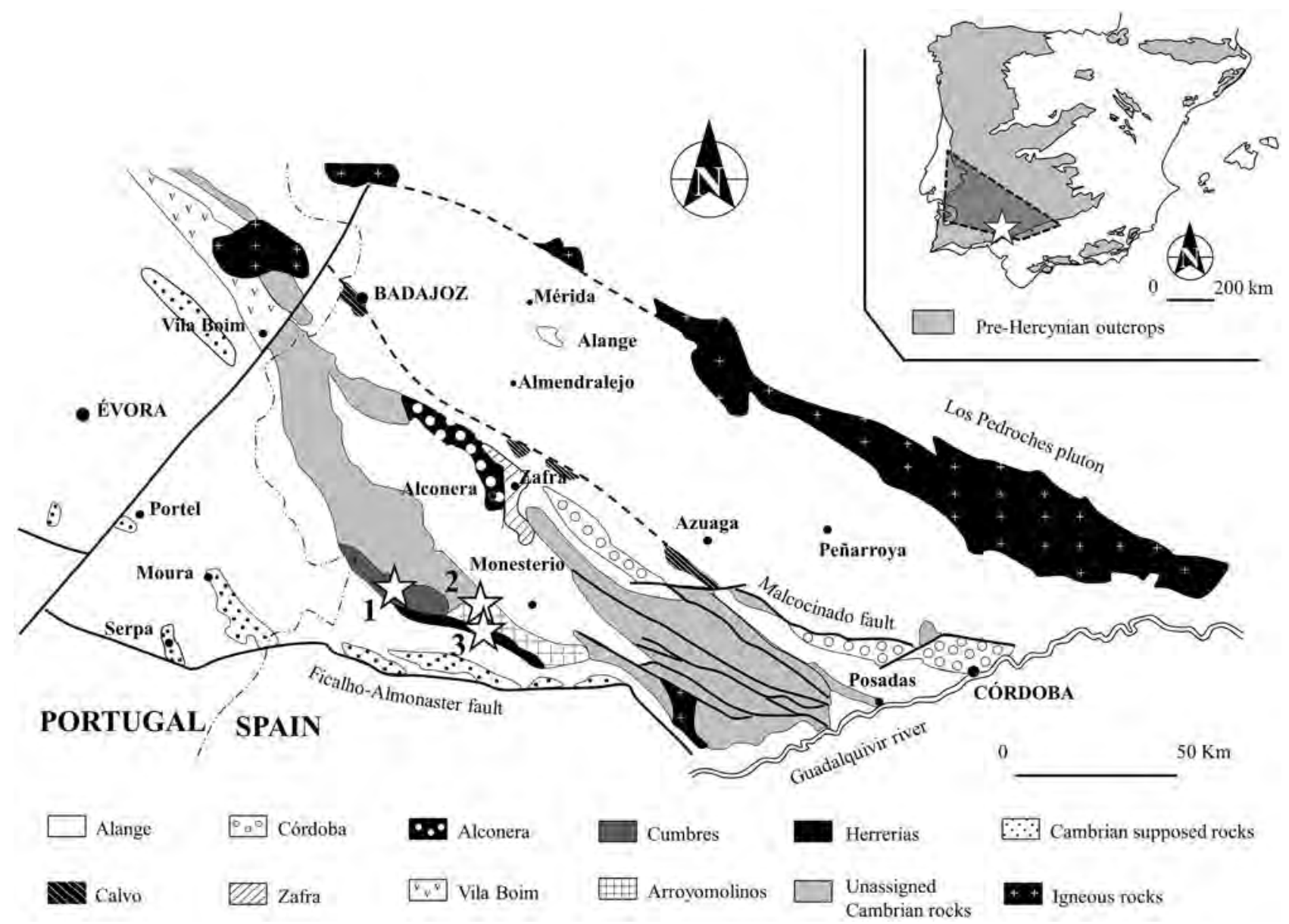

Figure 1. Geological setting of fossil sites in the Cambrian Cubetas (fault-bounded blocks) of the Ossa-Morena Zone, with white stars indicating the positions of the studied fossil sites in each Cubeta. 1 = Cumbres de San Bartolomé site (CU1); 2 = Arroyomolinos de León site (AM1-2); 3 = El Pozuelo site (POZ1). Modified from Liñán and Quesada (1990).

In the Arroyomolinos block (Arroyomolinos Cubeta), the Herrerías shale (300-400 m) includes purple, gray, and green shales, with metric intercalations of acid volcanic tuffs and spilites. Base and top of the $65-\mathrm{m}$ section at the AM1 collecting site are at $38^{\circ} 00^{\prime} 49.58^{\prime \prime} \mathrm{N}, 006^{\circ} 44^{\prime} 47.27^{\prime \prime} \mathrm{W}$ and $38^{\circ} 00^{\prime} 57.50^{\prime \prime} \mathrm{N}$, $006^{\circ} 24^{\prime} 50.14^{\prime \prime} \mathrm{W}$, respectively. Pseudatops reticulatus occurs with Serrodiscus silesius $46 \mathrm{~m}$ from the base. The AM2 section $\left(37^{\circ} 59^{\prime} 15.90^{\prime \prime} \mathrm{N}, 006^{\circ} 21^{\prime} 17.95^{\prime \prime} \mathrm{W}\right)$ is no longer accessible.

\section{Materials and methods}

The available material consists of isolated cranidia preserved as internal and external molds in purple shales with limonitic mineralization. Most of the studied specimens are deformed and/or fragmented.

Repositories and institutional abbreviations.-Figured specimens are housed in the Department of Earth Sciences (Laboratory of Tectonics and Paleontology) of the Faculty of Experimental Sciences, University of Huelva (UHU). Other cited repositories are: SMF = Senckenberg Museum, Frankfurt, Germany; USNM = Smithsonian Institution, National Museum of Natural History, Washington, DC.

\section{Systematic paleontology}

Class Trilobita Walch, 1771

Order uncertain

Family Atopidae Hupé, 1954

Included genera.-Atops Emmons, 1844 (=Ivshiniellus Korobov, 1966), Pseudatops Lake, 1940, and Atopina Korobov, 1966.

Diagnosis.-See Cotton (2001, p. 185, 186).

Remarks.-Cotton (2001) carried out a systematic review and a phylogenetic proposal of several blind ptychoparid trilobites, which had been previously included in Conocoryphidae, concluding that it was a polyphyletic group. Within that review, he amended the diagnosis of Atopidae, which he included within the superfamily Ellipsocephaloidea. Given the classification problems, Adrain (2011) proposed not to assign it to any order until a complete revision of the trilobite basal groups was carried out.

Jell et al. (1992) included Ivshiniellus nikolai Korobov, 1966, I. patulus Korobov, 1966, and I. briandailyi Jenkins 
and Hasenohr, 1989 in Atops. Cotton (2001) pointed out that in I. briandailyi, the tapering of the glabella represented in their reconstruction (Jenkins and Hasenohr, 1989, fig. 4) is not matched by that of the specimens, and the species closely resembles the other Australian species, Atops rupertensis Jell, Jago, and Gehling, 1992. We accept that Ivshiniellus is a junior subjective synonym of Atops as proposed by Jell et al. (1992) and Cotton (2001).

Jell et al. (1992) suggested that Atopina could be a junior synonym of Pseudatops, arguing that Atopina was erected based on distorted material, in which diagnostic differences compared to Pseudatops are due to tectonic distortion. The holotype of the type species Atopina antiqua Korobov, 1966 (figured by Korobov, 1973, pl. 12, fig. 5) shows several characters that resemble Pseudatops. However, the phylogenetic analysis carried out by Cotton (2001, figs. 2, 3) shows that Atopina is closer to Atops than to Pseudatops. Therefore, we prefer to keep Atopina as a separate genus, pending better-preserved specimens.

Several conocoryphids from the Sekwi Formation, Mackenzie Mountains, Canada (Fritz, 1973) have been moved to Atops (Jell et al., 1992; Cotton, 2001) based on their blindness, the form of the genal ridges, position of the suture, and glabellar taper. Monospecific Avalonia Walcott, 1890a was moved from Atopidae (Jell and Adrain, 2002) to the order Corynexochida based on the subquadrangular (Walcott, 1890a, p. 647) to anteriorly expanding (Walcott, 1890a, pl. 95, fig. 3) glabellar shape.

\section{Genus Atops Emmons, 1844}

Type species.—Atops trilineatus Emmons, 1844.

Other species. - Atops calanus Richter and Richter, 1941, Atops nikolai (Korobov, 1966), Atops patulus (Korobov, 1966), Atops granulatus Orlowski, 1985, Atops briandailyi (Jenkins and Hasenhor, 1989), Atops rupertensis Jell, Jago, and Gehling, 1992, Atops korobovi Romanenko in Repina et al., 1999, Atops sp. indet. of Cotton (2001), and Conocoryphidae gen. indet. sp. indet. of Fritz (1973).

Diagnosis.—See Jell et al. (1992, p. 192, 195).

Remarks.-The most notable differences between Atops and Pseudatops, according to Lake (1940) and Jell et al. (1992), are: (1) in Atops, the glabella extends to the anterior furrow, whereas in Pseudatops, it invades the anterior border; (2) in Atops, the anterior border furrow is deep, and the anterior border is slightly turned upward, whereas in Pseudatops, the anterior furrow is shallow, and the anterior border is flat or even downturned; (3) in Atops, the facial suture extends from the anterior to lateral margin across the anterior furrow, whereas in Pseudatops, the suture only cuts a small portion of the lateral border and the genal spine; and (4) Atops has granular ornament, but Pseudatops has reticulate ornament.

\section{Atops calanus Richter and Richter, 1941}

\section{Figure 2}

1941 Atops? calanus Richter and Richter, p. 55, pl. 3, fig. 41, pl. 4, fig. 63.

1958 Atops? calanus; Lotze, p. 743.
1961 Atops? calanus; Lotze, p. 164.

1961 Atops? calanus; Sdzuy, p. 230.

1962 Atops? calanus; Sdzuy, p. 212, pl. 23, figs. 14, ?15, 16.

2018 Atops sp. cf. calanus; Collantes et al., p. 567, fig. 4.7.

\section{Holotype.-SMF X 1227.}

Emended diagnosis._Atops with long, conical, tapered glabella, subtle ridge between anterior border furrow and preglabellar furrow. Glabella extends to marginal border furrow, giving rise to a preglabellar area laterally. Anterior border upturned, slightly convex anteriorly. Prominent occular ridge running laterally from frontal lobe. Suture cutting the gena close to the lateral furrow.

Occurrence.-The new specimens come from the upper part of Cumbres beds and Herrerías shale, late Marianian (Cambrian Stage 4). Richter and Richter (1941) cited Atops? calanus in their horizon cbM2/cbM3, which corresponds with the uppermost middle Marianian.

Description. - Cranidium subtrapezoidal, of pronounced relief, wider than long, 12.9-22.3 mm long, $19.4-41.8 \mathrm{~mm}$ wide. Opistoparian facial suture close to the lateral margin, cutting the gena near the lateral furrow. Straight or slightly curved anterior margin. Anterior border short (sag.), homogeneous, sloping upward from the anterior border furrow, turning upward. Anterior furrow pronounced, deep. Pregrablellar field short, laterally extended, subtrapezoidal. Preglabellar furrow slightly pronounced. Glabella conical, with rounded frontal lobe, gradually widened toward the posterior, with length equivalent to $4 / 5$ of the cephalon, with three pairs of deep, narrow, nontransglabellar furrows (S1-S3), slightly curving toward the posterior, all equal in length. Axial furrows narrow, deep, with a slightly convergent tendency toward the anterior area. Occipital furrow (S0) deep. Occipital lobe subtrapezoidal, planoconvex. Preocular field reduced, triangular. Preocular furrow deep, thin. Ocular ridge pronounced, connected between the frontal lobe of the glabella and the lateral furrow, presenting a slight curvature with convexity toward the front. Subtrapezoidal palpebral area wide, with slightly convex relief. Posterior furrow wide, deep, slightly curved. Posterior border thin (sag.), slightly curved. Subtriangular genal area, exsagital extension. Ornamentation composed of coarse granules with massive structure, more pronounced in the preocular and palpebral aresa and softer in the glabella. For reconstruction of the cephalon, see Figure 3.

Materials. - Seven partially preserved cranidia (UHU-CU100120, CU1010-CU1013-20, POZ020-20, AM1002-20). Additional fragments assigned to Atops calanus are deposited in the same collection.

Remarks.-The description above is based solely on the material collected for this study. Richter and Richter (1941) differentiated Atops? calanus from Atops trilineatus according to the distance between the anterior border furrow and the frontal lobe of the glabella, with a longer glabella reaching the anterior border in Atops trilineatus and a shorter, tapered glabella in Atops? 


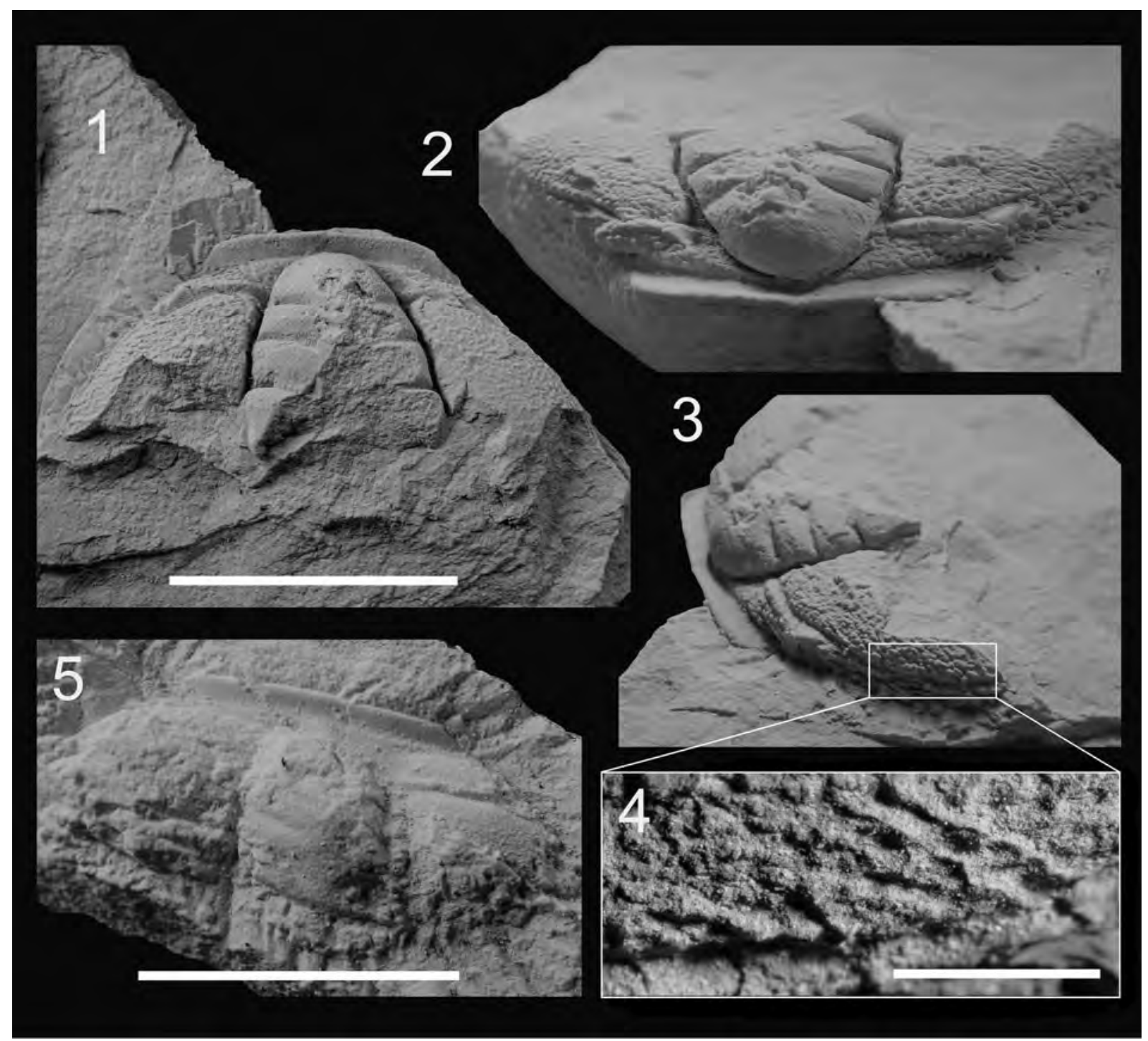

Figure 2. Atops calanus Richter and Richter, 1941: (1-4) UHU-CU1001-20, Cumbres de San Bartolomé, Cumbres beds, late Marianian: (1) dorsal view; (2) frontal view; (3) anterolateral view; (4) detail of the granular ornamentation; (5) UHU-CU1002-20, Cumbres de San Bartolomé, Cumbres beds, late Marianian, dorsal view. Scale bars $=20 \mathrm{~mm}$; scale bar for subfigure 4 is $5 \mathrm{~mm}$.

calanus, with a subtle ridge between anterior border furrow and preglabellar furrows. In Huelva specimens, these differences could be due to deformation and are not necessarily taxonomic characters (Fig. 2.1-2.3, note that the frontal lobe of the glabella invades the preglabellar field and reaches the anterior border due to deformation).

Atops rupertensis and Atops briandailyi from Australia are differentiated by the proportions of the cephalon, prominent parafrontal band, and a wide anterior border becoming narrower at the sides. Moreover, the glabella is considerably narrower and shorter with four pairs of thin, lateral, nontransglabellar furrows pointing backward and giving rise to less-pronounced glabellar lobes, and shallower, less-pronounced axial furrows. The palpebral area of both Atops rupertensis and Atops briandailyi is more extensive in proportion to the cephalon than in Atops calanus. In Atops rupertensis, the posterior furrow is shallower and broader
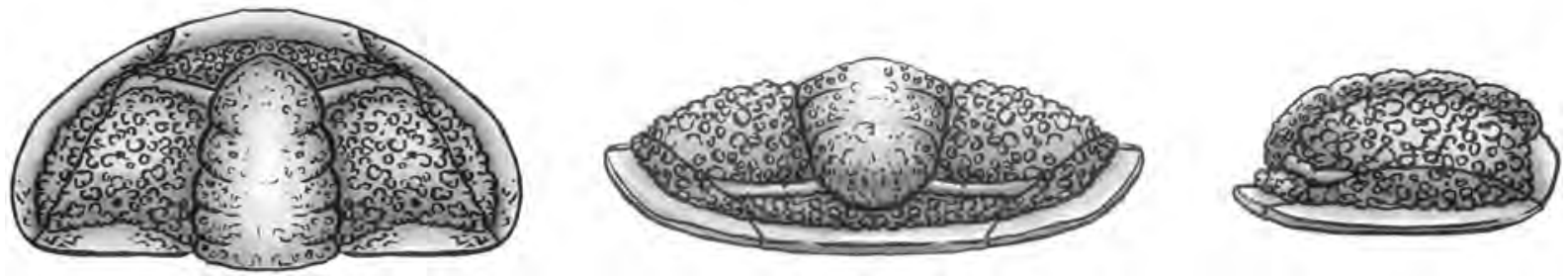

Figure 3. Reconstruction of the cephalon of Atops calanus Richter and Richer, 1941, in (left to right) dorsal, frontal, and lateral views. 
than in Atops calanus, becoming thicker at the sides. The posterior border is thin and uniform in both Atops calanus and Atops rupertensis.

Orlowski (1985) established Atops granulatus from the early Cambrian of the Holy Cross Mountains, Poland, and argued that Atops? calanus does not belong in Atops. The most distinctive characters of Atops granulatus are the parallelsided glabella, the lack of a preglabellar field, and the configuration of the glabellar furrows (S1 not parallel to S2 and S3). In contrast, Atops calanus has a tapered glabella and parallel glabellar furrows. In Atops granulatus, the facial suture extends across the lateral border, but in Atops calanus, the facial suture extends across the cheek to the ocular ridge, then to the genal area.

Atops korovobi from Russia is similar to Atops calanus but is distinguished by its more tapered frontal glabella lobe.

Ivshinellus nikolai and I. patulus, now both assigned to Atops (Jell et al., 1992), are based on distorted material (Korobov, 1973), but in comparison with Atops calanus, they show a subelliptical outline of the cephalon and a wider anterior border (especially in Atops nikolai). Furthermore, these Russian species have more narrowly triangular glabellae. Both Russian species also have subtler granular ornament.

Rushton (1966) described Atops? sp. indet. from the Purley Shales, England. The partial cranidium (Rushton, 1966, pl. 5, fig. 19) resembles Atops trilineatus especially in glabellar shape and suture configuration.

Conocoryphidae gen. indet. sp. indet. of Fritz (1973) has a conical glabella, narrower than in Atops calanus, a shorter plegabellar field, and coarse granular ornament all over the fixigenae and glabella.

Cotton's (2001, pl. 1, figs. 2-4) Atops sp. indet. from Saltwater Pond, Canada Bay, Newfoundland, has a higher glabella in comparison with the cephalon, a preglabellar field sagittally extended, and a wider anterior border. Despite these differences, it resembles Atops calanus in the outline of the cephalon, geometry of the glabella, and distribution of the granular ornamentation.

Genus Pseudatops Lake, 1940

Type species.—Conocoryphe reticulata Walcott, 1890b, by original designation (Lake, 1940, p. 291).

Other species.-Pseudatops viola Woodward, 1888, and Pseudatops perantiquus Korobov, 1973.

Emended diagnosis.-Atopidae with flat or slightly downward-turned anterior border; the absence of a preglabellar area due to the invasion of the frontal lobe of the glabella; the glabella reaching the anterior border; a facial suture that cuts only the genal spine and part of the lateral border; and bright, reticulated ornamentation.

Remarks.-Lake (1940) established Pseudatops as a result of the differences that he found between Atops trilineatus and Atops reticulatus var. comleyensis Cobbold, 1936, designating the latter species as type of the new genus.
Pseudatops reticulatus (Walcott, 1890b)

Figure 4

1890b Conocoryphe reticulata Walcott, p. 649, pl. 95, fig. 6, 6a. 1936 Atops reticulatus var. comleyensis Cobbold, p. 231, pl. 15, fig. 1a-e.

1940 Pseudatops reticulatus; Lake, p. 291, pl. 2, figs. 1-3.

2001 Pseudatops reticulatus; Cotton, pl. 2, figs. 1-3.

2006 Pseudatops reticulatus; Fletcher, pl. 27, fig. 21.

2018 Pseudatops n. sp.; Collantes et al., p. 567, fig. 4.8.

Holotype.-USNM 18431.

Emended diagnosis.-Pseudatops with trapezoidal cranidium, surrounded externally by a nearly flat border; elongated, subrectangular glabella and facial suture confined to the lateral border.

Occurrence.-Pseudatops reticulatus occurs in the Elliptocephala asaphoides Biozone in the Taconic Allochthon; in the Hebediscus attleborensis Subzone of the Callavia broeggeri Biozone in Avalonia; and in the upper Marianian of Iberia (herein).

Description.-Cranidium trapezoidal, wider than long, ranging $8.5-26.8 \mathrm{~mm}$ in length, $19.5-51 \mathrm{~mm}$ in width. Marginal facial suture only cutting the lateral border of the cephalon and not affecting the lateral furrow. Anterior margin slightly curved. Anterior border narrow (sag.), homogeneous, planoconvex, slightly turned downward. Anterior furrow shallow, sagittally invaginated toward the front due to the intrusion of the glabella, with a fairly broad and well-defined subtriangular shaped area originating on each side of the frontal lobe of the glabella. Glabella elongated, extending all along the cranidium, subrectangular, with rounded frontal lobe and deep axial furrows. Three pairs of nontransglabellar furrows with slight curvature pointing toward the posterior area. Occipital furrow deep, curving toward the front (convexity toward the posterior area). Occipital lobe narrow, trapezoidal, slightly curved with convexity toward the posterior area and subtle occipital tubercle. Preocular field slim, convex. Ocular ridge slightly pronounced, inserting toward the frontal lobe of the glabella and reaching the lateral furrow. Palpebral area flat, wide, trapezoid, with slight slope toward the posterior area. Posterior furrow well marked, wide. Posterior border narrow, flat, thickened near the genal area due to an incurved posterior border. Lateral border narrow, homogeneous. Genal angle $90^{\circ}$, with a minimal genal spine. Surface of the cephalon subtly reticulated. For reconstruction, see Figure 5.

Materials.-A total of 13 cranidial fragments were available (UHU-CU1002-CU1009-20, CU1014-CU1016-20, POZ02120, AM2001-20). Additional fragments are deposited in the same collection.

Remarks.-The description above is based solely on the material collected for this study.

The differences between North American Pseudatops reticulatus (New York and Newfoundland) and Spanish specimens 


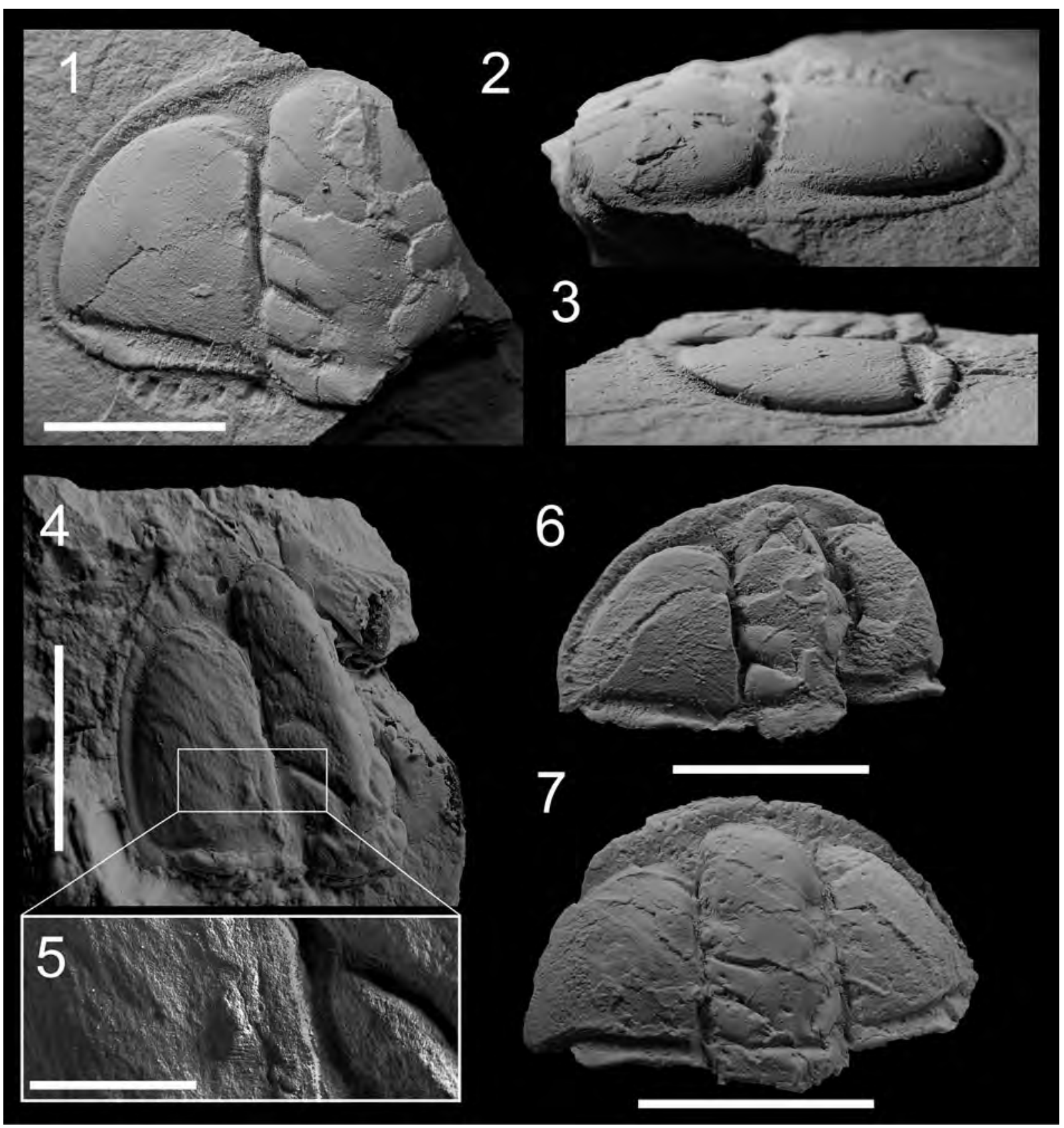

Figure 4. Pseudatops reticulatus (Walcott, 1890b): (1-3) UHU-CU003-20, Cumbres de San Bartolomé, Cumbres beds, late Marianian: (1) dorsal view; (2) frontal view; (3) lateral view; (4, 5) UHU-AM2001-20, Arroyomolinos de León, Herrerías shale, middle-late Marianian: (4) dorsal view; (5) detail of the reticular ornamentation; (6) UHU-CU1004-20, Cumbres de San Bartolomé, Cumbres beds, late Marianian, dorsal view; (7) UHU-CU1005-20, Cumbres de San Bartolomé, Cumbres beds, late Marianian, dorsal view. Scale bars $=20 \mathrm{~mm}$; scale bar for subfigure 5 is $5 \mathrm{~mm}$.

are minimal: the cephalon, especially the frontal lobe of the glabella, presents a more significant relief in the North American specimens. This could be taphonomic because the American specimens are preserved in limestone and the Spanish ones in shales.

Pseudatops viola has a cephalon with a semiovate outline, in contrast with the trapezoidal to semicircular cephalon of Pseudatops reticulatus. In Pseudatops viola, the facial suture crosses the lateral border furrow and a narrow sliver of the cheek, whereas in Pseudatops reticulatus, it is confined to the lateral border. The more marginal facial suture also occurs in numerous conocoryphids (see Sdzuy, 1961; Liñán and Gozalo, 1986).
Korobov (1973) erected Pseudatops perantiquus from the Ishim River, comparing it with Pseudatops viola and Pseudatops reticulatus. Pseudatops perantiquus differs from Pseudatops viola by a wider anterior border, wider anterior and posterior border furrows, and a subtriangular fixigena (Korobov, 1973). Pseudatops perantiquus has a wider cranidium, posterior border furrows running directly into the occipital furrow, a wider anterior border, and wider anterior and posterior furrows than Pseudatops reticulatus. Korobov (1973) noted that the Russian specimens have a wider, more uniform border in comparison with that of Pseudatops reticulatus. The smaller, conical glabella pointing forward and the three pairs of deep, wide lateral 

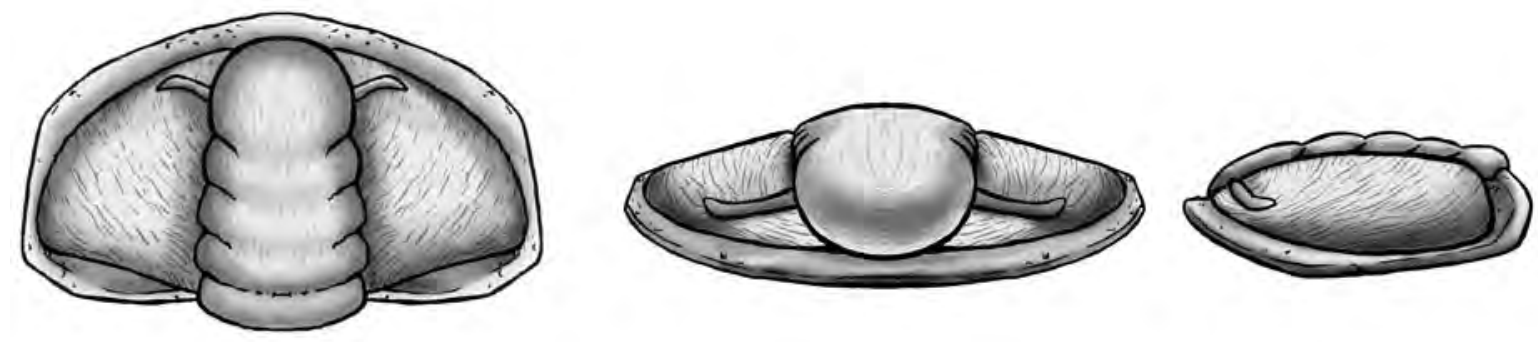

Figure 5. Reconstruction of the cephalon of Pseudatops reticulatus (Walcott, 1890b), in (left to right) dorsal, frontal, and lateral views.

furrows are especially remarkable. The frontal lobe of the glabella reaches the anterior furrow without invading the anterior border, but it has the characteristic reticulated ornament of Pseudatops.

\section{Discussion}

Biostratigraphy.-The Atopidae has a worldwide distribution. The stratigraphic distributions of Atops and Pseudatops are summarized in Figure 6.

Atops trilineatus occurs in the Taconic Allochthon, in the 'Lower Faunule' of the E. asaphoides Zone (Lochman, 1956; Rasetti, 1967). In Baltica, Atops granulatus occurs in the Holy Cross Mountains (Poland), in the middle Holmia-Schmidtiellus Biozone (Orlowski, 1985; Żylinska, 2013). Atops calanus occurs in the middle to late Marianian (Cambrian Stage 4) with Serrodiscus, Calodiscus, and Triangulaspis (Richter and Richter, 1941; Sdzuy, 1962; Collantes et al., 2018). In Australia, Atops rupertensis and A. briandailyi occur in the Pararaia janeae Biozone (Jell et al., 1992; Jago et al., 2006). Atops korobovi occurs in the Sanashtykgol Horizon of the Botomian stage in the Altai-Sayan Fold Belt (Repina et al., 1999). Atops nikolai and Atops patulus from Tuva Republic are from the upper Aldan Stage or, possibly, lowermost Lenan Stage (Korobov, 1973, table 1). Because the Lenan is now assigned to the Toyonian Stage (Astashkin et al., 1991), this species is likely upper Botomian. Atops? sp. indet. of Rushton (1966) from the Purley Shales (locality 2A) occurs with Serrodiscus ctenoa Rushton, 1966 of the Cephalopyge Biozone in the upper Cambrian Stage 4 (Rushton et al., 2011; Williams et al., 2013). Conocoryphidae gen. indet. sp. indet. of Fritz (1973) in the Mackenzie Mountains, northwestern Canada, assigned here to Atops, occurs in the lower Sekwi Formation, dated as Nevadella Biozone (upper Cambrian Stage 3 to lower Stage 4). Although Cotton (2001) did not offer information about the stratigraphic position of his Atops sp. indet., Murray studied the Salt Water Pond Series in 1864 (Murray and Howley, 1881; Schuchert and Dunbar, 1934) and the first three levels are included in the Forteau Formation (Betz, 1939, table 2), the horizon of which is assigned to the Bonnia-Olenellus Biozone, Dyeran Stage (Skovsted and Peel, 2007; Stouge et al., 2017).

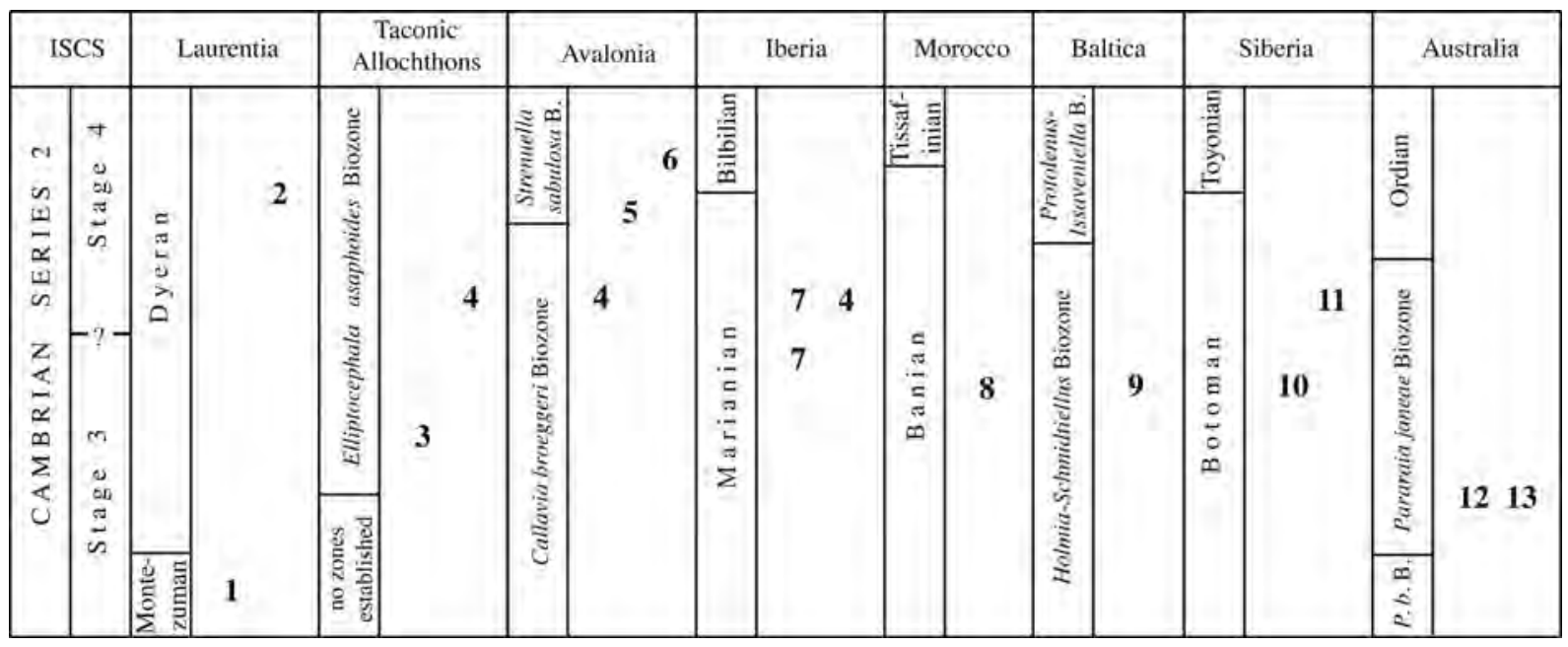

Figure 6. Correlation chart showing the stratigraphic occurrence of Atopidae. $1=$ Conocoryphidae gen. indet. sp. indet. of Fritz (1973); $2=$ Atops sp. indet. of Cotton (2001); 3 = Atops trilineatus Emmons, 1844; 4 = Pseudatops reticulatus (Walcott, 1890b); 5 = Pseudatops viola (Woodward, 1888); $6=$ Atops? sp. indet. of Rushton (1966); 7 = Atops calanus Richter and Richter, 1941; 8 = Pseudatops sp. indet. of Geyer in Sundberg et al. (2016); $9=$ Atops granulatus Orlowski, 1985; 10 = Atops nikolai (Korobov, 1966), Atops patulus (Korobov, 1966), Atopina antiqua Korobov, 1966, and Pseudatops perantiquus Korobov, 1973; $11=$ Atops korobovi Romanenko in Repina et al., 1999; 12 = Atops briandailyi (Jenkins and Hasenohr, 1989); 13 = Atops rupertensis Jell, Jago, and Gehling, $1992 ;$ B. = Biozone; P. $b$. B. = Pararaia bunyerooensis Biozone. Based on Sundberg et al. (2016); Zhang et al. (2017); and Geyer (2019). 


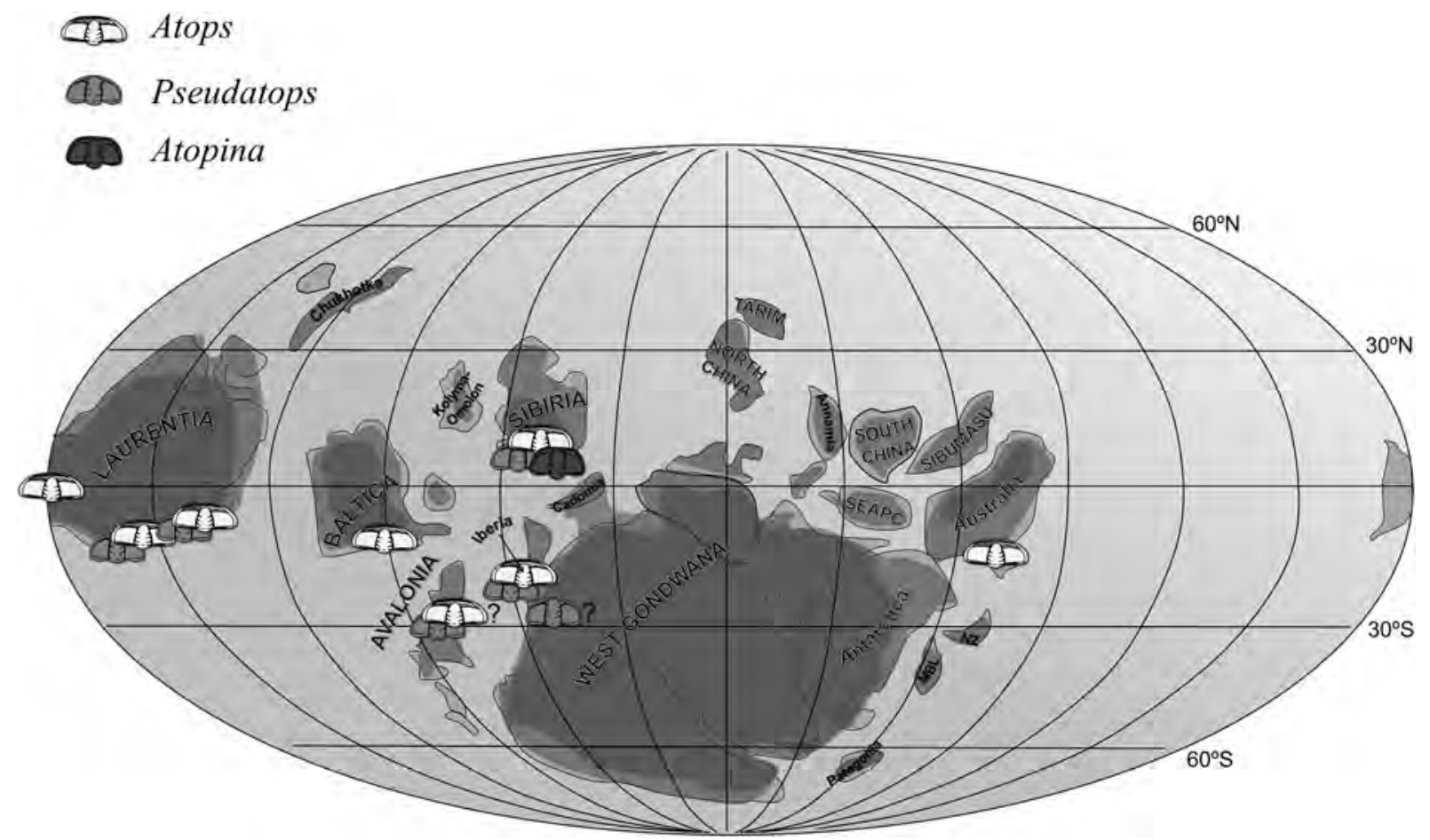

Figure 7. Distribution of the Atopidae, plotted on the Cambrian palaeogeographic map. Based on Dalziel (1997), Scotese and McKerrow (1990), McKerrow et al. (1992), and Malinky and Geyer (2019).

Pseudatops reticulatus is present in the 'Upper Faunule' of the E. asaphoides Zone in the Taconic Allochthon (Lochman, 1956; Basset et al., 1976); in the H. attleborensis Subzone of the C. broeggeri Zone of Avalonia (Fletcher, 2006); in horizon Ac3 of the Comley Limestones (Cobbold, 1921, 1936) of the Callavia Biozone (Thomas et al., 1984; Rushton et al., 2011) and Iberia, with Atops calanus, in the middle and lowermost late Marianian. In North Wales and Shropshire, Pseudatops viola appears in the Strenuella sabulosa Biozone (Howell and Stubblefield, 1950; Basset et al., 1976). In Morocco, Pseudatops is present in the Antatlasia guttapluviae Biozone (unpublished data, G. Geyer, according to Sundberg et al., 2016). Pseudatops perantiquus occurs in the Tuva Republic, in the CallaviaOlenellus-Holmia Biozone (Korobov, 1973, table 11).

Atopina is restricted to the Aldan Stage in Siberia (Korobov, 1973).

Paleobiogeography.-The Atopidae is known from Laurentia (northwestern Canada), the Taconic Allochthon (New York), western Newfoundland, western and eastern areas of Avalonia (eastern Newfoundland and the United Kingdom, respectively), Baltica (Poland), Siberia (Tuva Republic), the western margin of Gondwana (Iberia and Morocco), and Gondwana (Australia). Figure 7 shows that the distribution of Atopidae is mainly in the Southern Hemisphere, close to the equator.

\section{Acknowledgments}

We thank P. Jell (Queensland) and F.A. Sundberg (Arizona) for their constructive reviews, N. Hughes for his efforts in editing the article, I. Garzón and J. Ramírez for fieldwork assistance,
D. Jaramillo for English language revision, and G. Feria Marquínez for illustrations (Figs. 3,5). We want to thank the Council of Environment and Territorial Planning from the Junta de Andalucía and the Directorate of Sierra de Aracena y Picos de Aroche Natural Park for providing permission to work in the park. The present work was carried out with funding from the Junta de Andalucía to the RNM 276 Research Group and the Centro Científico-Tecnológico de Huelva to the Department of Applied Geosciences, together with the GIUV2017-395 research group of the University of Valencia. This work is a contribution to the projects IGCP 652 and 668.

\section{References}

Adrain, J.M., 2011, Class Trilobita Walch, 1771, in Zhang Z-Q., ed., Animal Biodiversity: An Outline of Higher Level Classification and Survey of Taxonomic Richness: Zootaxa, v. 3148, p. 104-109.

Astashkin, V.A., Pegel, T.V., Shabanov, Yu.Ya., Sukhov, S.S., Sundukov, V.M., Repina, L.N., Rozanov, A.Yu., and Zhuravlev, A.Yu., 1991, The Cambrian System on the Siberian Platform: Correlation Chart and Explanatory Notes: Herndon, Virginia, International Union of Geological Sciences, v. 27, 133 p.

Bassett, M.G., Owens, R.M., and Rushton, A.W.A., 1976, Lower Cambrian fossils from the Hell's Mouth Grits, St. Tudwal's Peninsula, North Wales: Journal of the Geological Society, v. 132, p. 623-644. doi:10.1144/ gsjgs.132.6.0623.

Betz, F., 1939, Geology and mineral deposits of the Canada Bay Area, northern Newfoundland: Geological Survey of Newfoundland Bulletin, v. 16, $53 \mathrm{p}$.

Cobbold, E.S., 1921, The Cambrian horizons of Comley (Shropshire) and thei Brachiopoda, Pteropoda, Gastropoda, etc: Quarterly Journal of the Geological Society of London, v. 76, p. 325-386.

Cobbold, E.S., 1936. The Conchostraca of the Cambrian area of Comley, Shropshire, with a note on a new variety of Atops reticulatus (Walcott): Quarterly Journal of the Geological Society of London, v. 92, p. 221-235. doi:10.1130/0016-7606(1997)109<0016:ONPGAT>2.3.CO;2.

Collantes, L., Gozalo, R, Mayoral, E., and Garzón, I., 2018, Trilobites del Cámbrico inferior (Marianiense) de la Unidad Fregenal-Cumbres (Sierra Norte de Huelva), in Vaz, N., and Sá, A.A., eds., Yacimientos Excepcionales de 
la Península Ibérica: Instituto Geológico y Minero de España, Madrid, Cuadernos del Museo Geominero, v. 27, p. 563-570.

Collantes, L., Mayoral, E., Chirivella Martorell, J.B., and Gozalo, R., 2020, New data on Marocella (Mollusca, Helcionelloida) from the Cambrian (Series 2-Miaolingian) of the Iberian Peninsula: GFF, v. 142, p. 190-205. doi: $10.1080 / 11035897.2020 .1762722$

Cotton, T.J., 2001, The phylogeny and systematics of blind Cambrian ptychoparioid trilobites: Paleontology, v. 44, no. 1, p. 167-207. doi:10.1111/ 1475-4983.00176

Dalziel, I.W.D., 1997, Neoproterozoic-Paleozoic geography and tectonics: Review, hypothesis, environmental speculation: Bulletin of the Geological Society of America, v. 109, p. 16-42.

Delgado, J.F.N., 1904, La faune cambrienne du Haut-Alentejo (Portugal): Comunicações dos Serviços Geológicos de Portugal, v. 5, p. 307-374.

Emmons, E., 1844, The Taconic system, based on observations in New York, Massachusetts, Maine, Vermont and Rhode Island: Albany, New York, Van Bethuysen, $65 \mathrm{p}$.

Fletcher, T.P., 2006, Bedrock geology of the Cape St. Mary's Peninsula, southwest Avalon Peninsula, Newfoundland (includes parts of NTS maps sheets $1 \mathrm{M} / 1,1 \mathrm{~N} / 4,1 \mathrm{~L} / 6$ and $1 \mathrm{~K} / 13$ ), Newfoundland: Newfoundland and Labrador, Department of Natural Resources, Geological Survey, Report 06-02, 117 p.

Fritz, W.H., 1973, Medial lower Cambrian trilobites from the Mackenzie Mountains, northwestern Canada: Geological Survey of Canada, paper 73-24, p. 1-43.

Geyer, G., 2019. A comprehensive Cambrian correlation chart: Episodes, v. 42, p. 321-332. doi:10.18814/epiiugs/2019/019026.

Harrington, H.J., Henningsmoen, G., Howell, B.F., Jaanuson, V., LochmanBalk, C., Poulsen, C., Rasetti, F., Richter, E., Richter, R., Schmidt, H., Sdzuy, K., Struve, W., Stormer, L., Stubblefield, C.J., Tripp, R., Weller, J.M., and Whittington, H.B., 1959, Treatise on Invertebrate Paleontology, Part O, Arthropoda 1: Boulder, Colorado, and Lawrence, Kansas, Geological Society of America (and University of Kansas Press), 560 p.

Howell, B.F., 1935, Cambrian and Ordovician trilobites from Hérault, southern France: Journal of Paleontology, v. 9, p. 222-238.

Howell, B.F., and Stubblefield, C.J., 1950, A revision of the fauna of the north Welsh Conocoryphe viola beds implying a lower Cambrian age: Geological Magazine, v. 87, p. 1-16. doi:10.1017/S0016756800075506.

Hupé, P., 1953, Contribution a l'etude du Cambrien inferieur et du Precambrien III de l'Antiatlas marocain: Notes et Memoires, Service des Mines et de la Carte geologique du Maroc, v. 103, p. 1-402.

Hupé, P., 1954, Trilobites, in Piveteau, J., ed., Traité de Paléontologie, Tome 3 : Paris, Masson et Cie, p. 44-246.

Jago, J.B., Zang, W.-L., Sun, X., Brock, G.A., Paterson, J.R., and Skovsted, C.B., 2006, A review of the Cambrian biostratigraphy of South Australia: Paleoworld, v. 15, p. 406-423. doi:10.1016/j.palwor.2006.10.014.

Jell, P.A., and Adrain, J.M., 2002, Available generic names for trilobites: Memoirs of the Queensland Museum, v. 48, no. 2, p. 331-553.

Jell, P.A., Jago, J.B., and Gehling, J.G., 1992, A new conocoryphid from the lower Cambrian of the Flinders Ranges, South Australia: Alcheringa, v. 16, p. 189-200. doi:10.1080/03115519208619118

Jenkins, R.J.F., and Hasenhohr, P., 1989, Trilobites and their trails in a black shale: Early Cambrian of the Fleurieu Peninsula, South Australia: Transactions of the Royal Society of South Australia, v. 113, p. 195-203.

Korobov, M.N., 1966, New trilobites of the family Conocoryphidae from the Cambrian of the Siberian Platform and Tuva: Paleontologicheskiy Zhurnal, v. 1966, p. 92-97. [in Russian]

Korobov, M.N., 1973, [The trilobite family Conocoryphidae and its significance to the stratigraphy of the Cambrian deposits]: Moscow, Trudy Geologicheskogo Instituta, v. 211, 176 p. [in Russian]

Lake, P., 1940, A monograph of the British Cambrian trilobites, Part 12: Palaeontographical Society Monographs, v. 94, p. 273-306.

Lermontova, E.V., 1940, Klass trilobity, in Vologdin, A.G., ed., Atlas Rukovodyashchikh Form Iskopaemykh Faun SSSR, 1, Kembriy: Moscow, State Editorial Office for Geological Literature, p. 112-162.

Lieberman, B. S., 2001, Phylogenetic analysis of the Olenellina Walcott, 1890 (Trilobita, Cambrian): Journal of Paleontology, v. 75, p. 96-115.

Liñán, E., and Gozalo, R., 1986, Trilobites del Cámbrico Inferior y Medio de Murero (Cordillera Ibérica): Memorias del Museo Paleontológico de la Universidad de Zaragoza, v. 2, $104 \mathrm{p}$.

Liñán, E., and Mergl, M., 1982, Lower Cambrian brachiopods of Sierra Morena: Boletin de la Real Sociedad Española de Historia Natural, Geología. v. 80, p. 207-220.

Liñán, E., and Quesada, C., 1990, Ossa-Morena Zone, Stratigraphy, Rift phase (Cambrian), in Dallmeyer, R.D., and Martínez García, E., eds., PreMesozoic Geology of Iberia: Berlin, Springer-Verlag, p. 259-266.

Liñán, E., Gozalo, R., Palacios, T., Gámez Vintaned, J.A., Ugidos, J.M., and Mayoral, E., 2002, Cambrian, in Gibbons, W., and Moreno, T., eds., The Geology of Spain: London, Geological Society, p. 17-29. doi:10.1144/GOSPP.3.

Lochman, C., 1956, Stratigraphy, paleontology, and paleogeography of the Elliptocephala asaphoides strata in Cambridge and Hoosick Quadrangles,
New York: Bulletin of the Geological Society of America, v. 67, p. 1331-1396.

Lotze, F., 1958, Zur Stratigraphie des spanischen Kambriums: Geologie, v. 7, p. $727-750$.

Lotze, F., 1961, Das Kambrium Spaniens, Teil 1, Stratigraphie: Stuttgart, Germany, Akademie der Wissenschaften und der Literatur, Abhandlungen der Mathematisch-Naturwissenschaftlichen Klasse, v. 1961, 216 p.

Malinky, J.M., and Geyer, G., 2019, Cambrian Hyolitha of Siberian, Baltican and Avalonian aspect in east Laurentian North America: Taxonomy and palaeobiogeography: Alcheringa, v. 43, no. 2, p. 171-203. doi:10.1080/ 03115518.2019.1567813.

McKerrow, W.S., Scotese, C.R., and Brasier, M.D., 1992, Early Cambrian continental reconstructions: Journal of the Geological Society, v. 149, p. 599-606. doi:10.1144/gsjgs.149.4.0599.

Murray, A., and Howley, J.P., 1881, Geological Survey of Newfoundland, 1864-1880, Reprints of Reports, Revised and Corrected: London, Geological Survey of Newfoundland, $536 \mathrm{p}$.

Orlowski, S., 1985, A trilobite with North American affinity in the lower Cambrian of Poland: Journal of Paleontology, v. 59, p. 975-978.

Rasetti, F., 1967, Lower and middle Cambrian trilobite faunas from the Taconic sequence of New York: Smithsonian Miscellaneous Collections, v. 152, $111 \mathrm{p}$.

Repina, L.N., Romanenko, E.V., Fedjanina, E.S., and Pegel, T.V., 1999, Trilobites from the lower and lowermost middle Cambrian of the Kiya River Reference Section (Kuznetsk Alatau): Annales de Paléontologie, v. 85, no. 1, p. 3-56.

Richter, R., and Richter, E., 1940, Die Saukianda-Stufe von Andalusien, eine fremde Fauna in europäischen Ober-Kambrium: Abhandlungen der Senckenbergische Naturforschenden Gessellschaft, v. 450, p. 1-88.

Richter, R., and Richter, E., 1941, Die Faune des Unter-Kambrians von Cala in Andalusien: Abhandlugen der Senckenbergische Naturforschenden Gessellschaft, v. 455, p. 1-90.

Ruiz López, J.L., Fernández Carrasco, J., Collaut Saenz de Sicilia, J.L., and Apalategui, O., 1979, Memoria de la Hoja N 896 (Higuera la Real), Mapa Geológico de España E., 1:50.000 (MAGNA), Segunda Serie, Primera Edición: Madrid, Instituto Geológico y Minero de España, 47 p.

Rushton, A.W.A., 1966, The Cambrian trilobites from the Purley Shales of Warwickshire: Palaeontographtcal Society Monographs, v. 120, p. 1-55.

Rushton, A.W.A., Brück, P.M., Molyneux, S.G., Williams, M., and Woodcock, N.H., 2011, A Revised Correlation of the Cambrian Rocks in the British Isles: London, Geological Society, v. 25, 62 p.

Schuchert, C., and Dunbar, C.O., 1934, Stratigraphy of western Newfoundland: Geological Society of America Memoir, v. 1, 123 p.

Scotese, C.R., and McKerrow, W.S., 1990, Revised world maps and introduction, in McKerrow, W.S., and Scotese, C.R., eds., Palaeozoic Palaeogeography and Biogeography: Geological Society of London Memoir, v. 12, p. $1-21$.

Sdzuy, K., 1961, Das Kambrium Spaniens, Teil 2, Trilobiten: Akademie der Wissenschaften und der Literatur, Abhnadlungen der mathematischnaturwissenschaftlichen Klase, v. 1961, no. 7/8, p. 217-408.

Sdzuy, K., 1962, Trilobiten aus dem Unter-Kambrium der Sierra Morena (S. Spanien): Senckenbergiana Lethaea, v. 43, p. 181-229.

Skovsted, C.B., and Peel, J.S., 2007, Small shelly fossils from the argillaceous facies of the lower Cambrian Forteau Formation of western Newfoundland: Acta Palaeontologica Polonica, v. 52, p. 729-748.

Stouge, S., Bagnoli, G., and McIlroy, D., 2017, Cambrian-Middle Ordovician platform-slope stratigraphy, palaeontology and geochemistry of western Newfoundland: International Symposium on the Ediacaran-Cambrian Transition: Field Trip 2, Open-File Report NFLD/3325, 106 p.

Sundberg, F.A., Geyer, G., Kruse, P.D., McCollum, L.B., Pegel, T.V., Żylinska, A., and Zhuravlev, A., 2016, International correlation of the Cambrian Series 2-3, Stages 4-5 boundary interval: Australasian Palaeontological Memoirs, v. 49 , p. $83-124$.

Thomas, A.T., Owens, R.M., and Rushton, A.W.A., 1984, Trilobites in British Stratigraphy: Special Report, Geological Society of London, v. 16, $78 \mathrm{p}$.

Walch, J.E.I., 1771, Die Naturgeschichte der Versteinerungen zur Erläuterung der Knorrischen Sammlungen von Merkwürdigkeiten der Natur: Nürnberg, Germany, Felßecker, 235 p.

Walcott, C.D., 1890a, Descriptive notes of new genera and species from the lower Cambrian or Olenellus Zone of North America: Proceedings of the United States National Museum, v. 12, p. 33-46.

Walcott, C.D., 1890b, The fauna of the lower Cambrian or Olenellus Zone: Annual Report of the United States Geological Survey, Part 1, Geology, p. 509-760, pls. 43-98.

Walcott, C.D., 1912, Cambrian Brachiopoda: United States Geological Survey, Monograph, v. 51, p. 1-872.

Williams, M., Rushton, A.W.A., Cooks, A.F., Zalasiewicz, J., Martin, A.P., Condon, D.J., and Winrow, P., 2013, Dating the Cambrian Purley Shale 
Formation, Midland Microcraton, England: Geological Magazine, v. 150, no. 5, p. 937-944. doi:10.1017/S0016756813000010.

Woodward, H., 1888, On the discovery of trilobites in the Upper Green (Cambrian) Slates of the Penrhyn Quarries, Bethesda, near Bangor, North Wales: Quarterly Journal of the Geological Society of London, v. 44 p. 74-78.

Yochelson, E.L., and Gil Cid, M.D., 1984. Reevaluation of the systematic position of Scenella: Lethaia, v. 17, p. 331-340.

Zhang, X., Ahlberg, P., Babcock, L.E., Choi, D.K., Geyer, G., Gozalo, R., Hollingsworth, J.S., Li, G., Naimark, E.B., Pegel, T., Steiner, M., Wotte, T., and
Zhang, Z., 2017, Challenges in defining the base of Cambrian Series 2 and Stage 3: Earth-Science Reviews, v. 172, p. 124-139. doi:10.1016/ j.earscirev.2017.07.017.

Zylińska, A., 2013, Ewolucja zespołów trylobitowych z drugiego i trzeciego oddziału kambru Gór Swietokrzyskich i ich znaczenie biogeograficzne: Przeglad Geologiczny, v. 61, no. 1, p. 30-39.

Accepted: 9 August 2020 